Isabel Fernández Alonso and María-Jesús Díaz-González

Autonomous University of Barcelona's Communication Institute

\title{
Pluralism in Crisis: Transformations of the Spanish DTT Market in the Context of the Recession
}

\begin{abstract}
This article discusses the most significant aspects of DTT's evolution in Spain since the analogue switch-off in April 2010. It underscores the severe cutbacks affecting publicservice television broadcasters and their impact, as well as a return to government control over the Spanish Broadcasting Corporation (RTVE) in particular. It also emphasises the major tendency towards concentration in the national private DTT market and the inviability of most regional and local broadcasters. All of these issues are analysed from the perspective of their worrying impact on pluralism.
\end{abstract}

\section{Keywords:}

DTT

Pluralism

Spain

public-service media

financial crisis

concentration

By the time Spain's analogue switch-off took place in April 2010, terrestrial television offerings had multiplied nationally (from five analogue channels to 20 digital channels) and regionally (with the emergence of new regional private broadcasters and an increase in the number of public-service broadcasters), and had become regulated locally (while local analogue broadcasters had begun operating in the early 1980s, they never had broadcasting licences).

Besides the national public-service television broadcaster (for which two postswitch-off multiplexes had been set aside), a number of private communication groups were called upon at that time to consolidate the national Digital Terrestrial Television (DTT) market (insofar as they would each have a full multiplex). These groups were Planeta, Imagina Media Audiovisual, PRISA and Vocento (all majority Spanish owned), and Unidad Editorial (a subsidiary of the Italian RCS MediaGroup) and Gestevisión Telecinco (a subsidiary of Mediaset Italia). PRISA and Vocento had also made a considerable commitment to regional private DTT.

However, signs pointing to a weakening of pluralism in the television market had already begun to show. The most noteworthy of these was the advanced stage of negotiations for Gestevisión Telecinco (now Mediaset España) to gain control of PRISA's national DTT licence. Here, it is necessary to clarify that, besides being politically progressive, PRISA was Spain's main media group. If that deal were sealed, then only one private and politically progressive media group holding a national DTT licence would remain -Imagina Media Audiovisual, which had also entered into negotiations with the politically conservative Planeta group to merge their television businesses.

Other worrying signs for pluralism were the fragility of projects emerging from regional private DTT (particularly affected by the advertising recession) and the problems that local broadcasters faced in terms of adapting to the new markets that had 
been generated by the delimitation of fairly large coverage areas that conformed to technical rather than historico-cultural criteria.

Below, we shall see how, between 2010 and 2012, various economic and political factors have placed the pluralism of the public and private DTT offerings at considerably greater risk. This is a particularly serious matter when analysed in the light of the harsh public-spending cutback policies that are being implemented by Spain's new conservative government (Partido Popular), which are systematically presented as the only way of overcoming the financial crisis.

\section{Greater cutbacks and more political control in public DTT}

Many scholarly works and international organisations (UNESCO, European Union and the Council of Europe) have underscored the vital role that public-service media play as guarantors of media pluralism and, in consequence, of democratic debate. In this respect, Spain has stood out over the last three decades for almost certainly being the European country with the broadest range of public-service television offerings, with its national, regional and local broadcasters. It should be noted, however, that such media have often been highly politicised and/or the subjects of government interference.

DTT roll-out initially seemed to be aimed at strengthening this model, but the severe public-spending cutbacks resulting from the financial crisis have particularly affected public-service television broadcasters (whose channel offerings had multiplied excessively, if market size and funding potential are taken into account)), thus weakening their roles in the television market.

In the case of Radiotelevisión Española (RTVE, Spanish Broadcasting Corporation), its funding model was changed just before the analogue switch-off. To be precise, advertising as a source of funding was abolished in January 2010 and replaced by a number of taxes, meaning that the corporation's budget has become dependent on the gross operating turnover of private television broadcasters and telecommunications companies (with the risk, in the case of the latter, of the tax being considered unlawful by the courts for being in breach of EU law). In addition, there has been a $€ 204$.8million reduction in public subsidies in the 2012 financial year, which has already led to drastic cuts in stellar content on Televisión Española (Spanish Television, TVE) and in employees' pay. While the possibility of abolishing one of TVE's two post-switch-off multiplexes has been mentioned more than once, no firm action had been taken on this issue at the time of writing (late 2012).

Regarding regional public-service television broadcasters (13 of Spain's 17 autonomous communities each have their own), some examples of the impact of various cutback decisions made in 2012 are the downsizing plan affecting 75\% of the workforce of Radiotelevisión Valenciana (Valencian Broadcasting Corporation), the axing of the second television channels in the regional public-service broadcasters of the Canary Islands and Andalusia, respectively, the elimination of a channel and the merging of two others in Catalonia, and the potential closure of Murcia's public-service television broadcaster altogether, since it only broadcasts canned programmes.

In parallel to such cutbacks, Spain's new conservative government (Partido Popular) promulgated a counter-reform of RTVE's governance model in April 2012, which once again placed the public-service broadcaster under government control by abolishing the obligation to reach a consensus with the main opposition party on the appointment of the chairperson and board of RTVE. The changes made to the management team in 2012 led to the immediate departure of renowned reporters and the gradual loss of TVE's newscast leadership (its general leadership had already been lost as a result of the above-mentioned cutbacks). 
Regionally, other worrying signs for pluralism have also begun to show. On the one hand, the counter-reform of the governance model of the Catalan Broadcasting Corporation (very similar to, and promulgated at practically the same time as that of RTVE), which many saw as the precursor to autonomous-community regulation favouring the independence of public-service media. And on the other hand, the growing trend towards the regional public-service television broadcasters' outsourcing of management (including of newscasts), from which two production groups are especially benefitting (Vértice 360 and Secuoya), both of which are connected with the current governing party in Spain.

\section{More concentration and channel closures in private DTT}

Following the analogue switch-off referred to earlier, each of the national private DTT licence-holders had one full multiplex (TVE had two). As a result, the total offerings had increased from 20 to 28 channels by September 2012 (see Table 1).

Table 1. National DTT offerings in Spain (2012)

\begin{tabular}{|c|c|c|}
\hline $\begin{array}{l}\text { Licence-holding company } \\
\text { (reference shareholders) }\end{array}$ & Channels & $\begin{array}{l}\text { Audience share } \\
\text { July } 2012 \\
\text { according to Kantar } \\
\text { Media }\end{array}$ \\
\hline $\begin{array}{l}\text { Televisión Española, S.A. } \\
\text { (public-service broadcaster) }\end{array}$ & $\begin{array}{l}\text { La } 1 \\
\text { La } 2 \\
\text { Canal 24horas } \\
\text { Clan } \\
\text { Teledeporte } \\
\text { TVE HD (being tested) }\end{array}$ & $\begin{array}{l}10.7 \% \\
2.6 \% \\
1.1 \% \\
2.8 \% \\
1.4 \% \\
-\quad \\
\end{array}$ \\
\hline $\begin{array}{l}\text { Antena } 3 \text { de Televisión S. A. } \\
\text { (Planeta de Agostini) }\end{array}$ & $\begin{array}{l}\text { Antena } 3 \\
\text { Antena } 3 \text { HD (simulcast) } \\
\text { Neox } \\
\text { Nova } \\
\text { Nitro }\end{array}$ & $\begin{array}{l}12.5 \% \\
- \\
2.8 \% \\
1.7 \% \\
1.8 \% \\
\end{array}$ \\
\hline $\begin{array}{l}\text { Gestora de Inversiones Audiovisuales } \\
\text { La Sexta, S. A. } \\
\text { (Imagina Media Audiovisual, until taken over } \\
\text { by Antena } 3 \text { de Televisión S. A. in October } \\
\text { 2012) }\end{array}$ & $\begin{array}{l}\text { La Sexta } \\
\text { La Sexta HD (simulcast) } \\
\text { Xplora } \\
\text { La Sexta } 3 \\
\text { Gol TV (pay-TV) }\end{array}$ & $\begin{array}{l}.6 \% \\
- \\
1.5 \% \\
1.8 \% \\
- \\
\end{array}$ \\
\hline $\begin{array}{l}\text { Mediaset España Comunicación, S. A. } \\
\text { (Mediaset Investimenti, S.P.A. and PRISA) }\end{array}$ & $\begin{array}{l}\text { Telecinco } \\
\text { Telecinco HD (simulcast) } \\
\text { FDF } \\
\text { La Siete } \\
\text { Cuatro } \\
\text { Cuatro HD (simulcast) } \\
\text { Divinity } \\
\text { Boing } \\
\text { Energy } \\
\text { La Tienda en Casa }\end{array}$ & $\begin{array}{l}13.3 \% \\
- \\
3.4 \% \\
1.4 \% \\
5.7 \% \\
- \\
1.5 \% \\
2.1 \% \\
0.9 \% \\
-\end{array}$ \\
\hline $\begin{array}{l}\text { Veo Televisión, S. A. } \\
\text { (Unidad Editorial, subsidiary of RCS } \\
\text { MediaGroup) }\end{array}$ & $\begin{array}{l}\text { Marca TV } \\
\text { Discovery Max } \\
13 \mathrm{TV} \\
\text { AXN (pay-TV) }\end{array}$ & $\begin{array}{l}0.7 \% \\
1.4 \% \\
1 \% \\
-\end{array}$ \\
\hline $\begin{array}{l}\text { Sociedad Gestora de Televisión Net TV, S. } \\
\text { A. } \\
\text { (Vocento, Intereconomía, Disney) }\end{array}$ & $\begin{array}{l}\text { Intereconomía } \\
\text { Disney Channel } \\
\text { MTV } \\
\text { Paramount Channel }\end{array}$ & $\begin{array}{l}1.1 \% \\
1.8 \% \\
0.8 \% \\
1.1 \%\end{array}$ \\
\hline
\end{tabular}


However, if these offerings are analysed from the viewpoint of pluralism, it is possible to find two concentration actions that turn the owners of the two historical freeto-air analogue television broadcasters (Telecinco and Antena 3) into the clear dominators of the Spanish advertising market, since together they control more than $80 \%$ of it.

The background to this is that, in December 2010, Mediaset España Comunicación (formerly Gestevisión Telecinco) bought the national free-to-air television business from PRISA, which explains why the Spanish subsidiary of the group linked to the Berlusconi family now has two multiplexes. More recently, in July 2012, the CNC (Spanish National Competition Commission) gave the green light to another takeover: that of the licence belonging to Gestora de Inversiones Audiovisuales La Sexta S.A. (Imagina Media Audiovisual) by Antena 3 de Televisión S. A. (Planeta), which, like Mediaset, allowed Planeta to have two multiplexes. In this case, however, the buying group did not accept the conditions imposed and appealed to Spain's Council of Ministers, which, on 24 August 2012, agreed to soften the conditions, particularly in relation to the commercialisation of advertising slots. In the interim, the CNC has initiated two sanction proceedings against Mediaset España for its systematic breach of the conditions imposed on the above-mentioned takeover.

A key question mark hanging over these market operations is whether the channel La Sexta will retain its editorial profile as announced by Planeta to its investors. It is a very important question because La Sexta is the only politically progressive generalist channel to survive in the national DTT market since PRISA's withdrawal from it.

In any case, Mediaset's and Planeta's weight in the terrestrial television market is now even greater given the weakness of other DTT projects, a good example of which is the fact that both Vocento and RCS MediaGroup have resorted to programme rental (the case of $13 \mathrm{TV}$ ) or content supply agreements (Discovery Max, AXN, MTV, Paramount Channel), while renouncing their generalist offerings: the channels Veo 7 and La 10 stopped broadcasting at the end of 2011 because they were not financially viable.

Regarding regional private DTT, it is even more affected by the advertising market recession than national DTT. This is borne out by the fact that two of the three large Spanish groups (PRISA and Vocento) that had made a considerable commitment to this sector are no longer providing a regional service, while the third group (COPE), whose main shareholder is the Spanish Episcopal Conference, has chosen to rent a channel (13 TV) from RCS MediaGroup in order to focus on the national business, leaving the regional channels to be managed by its various regional partners.

Finally, local private and public DTT continues to be a much more fragile sector. Many projects that obtained licences have not become operational, and those that have are closing down one after another, basically because their dependence on propertymarket advertising and local-council subsidies has been too great. Indeed, local councils themselves are now in an extremely precarious economic position.

\section{Grim prospects}

Given all of the above, the DTT roll-out model in Spain can be deemed a failure (undeniably hastened by the financial crisis), especially when considering that its promoters stressed that a much more diverse television offering would be good for pluralism. Moreover, there are currently no signs pointing to anything resembling an encouraging reformulation of public policies or business strategies, since both are clearly limited by the recession. 
An example of this is the Spanish Council of Ministers' approval, on 24 August 2012, of the DTT and technological innovation impetus plan, which brings forward digital dividend deregulation to January 2014 to facilitate the roll-out of $4 \mathrm{G}$ mobile telephony from that date. This decision was reached with the consensus of the trade body UTECA (Associated Commercial Television Union). And while announcing a reduction in the number of frequencies for DTT and an impetus for high definition, in principle it does not entail a reconfiguration of the offerings that such technological advances are able to facilitate.

In short, it is a really worrying outlook, with renewed government interference in the national public-service television broadcaster and a very scarce presence of private broadcasters that are critical of the increasingly contested policies being applied in a country where $70 \%$ of all citizens rely on television to find out what is happening in the world.

\section{Notes}

(1) This text was written within the framework of a RD\&I project funded by the Spanish Ministry of Science and Innovation: The Rollout of DTT in Spain and the Impact on Pluralism (CSO2010-17898, sub-programme COMU). Originally in Spanish, the text was translated into English by Steven Norris.

(2) To find out more about the DTT roll-out process in Spain between 1998 and 2010 from a political perspective, see the article "Digital Terrestrial Television roll-out policies in Spain and the changing television scene in the context of analogue switchoff' by the authors of the present article, published in this journal: Vol. 1, Iss. 3, 2010, pp. 289-307.

\section{Authors}

Isabel Fernández Alonso is a tenured lecturer in the Department of Media, Communication and Culture at the Autonomous University of Barcelona (UAB), Spain, and director of the Communication Policies Observatory, also at the UAB.

María-Jesús Díaz-González is a lecturer in the Faculty of Communication Sciences at the University of A Coruña, Spain, and a member of the research team for the Communication Policies Observatory at the Autonomous University of Barcelona's Institute of Communication (InCom-UAB). 